\title{
т.п. попович
}

Терезія Петрівна Попович, кандидат юридичних наук, доцент, доцент ДВНЗ «Ужгородський національний університет»*

ORCID: 0000-0002-8333-3921

\section{ЮРИДИЧНИЙ ОБОВ'ЯЗОК ЯК ПРАВОВА ЦІННІСТЬ}

Постановка проблеми. Проблематика цінностей та ціннісних орієнтацій є однією 3 пріоритетних у сучасних суспільно-гуманітарних дослідженнях у зв'язку з глобалізаційними тенденціями, прагненням до універсалізації статусу людини, що сприяє формуванню нового образу людини майбутнього. Подібні напрями наукових пошуків захоплюють значною мірою й правову сферу. Актуальність дослідження юридичного обов'язку як правової цінності пов'язується передусім концептуальним зрізом розуміння сучасною правовою наукою сфери права як сфери правових цінностей, де кожне правове явище сприймається насамперед в його оцінці особою та суспільством у цілому. Вказане підтверджується наявними науковими розвідками проблем юридичних обов'язків та правових цінностей. Що стосується юридичного обов'язку, то звернення дослідників до даної проблематики можливо пояснити досить довгим «забуттям» цього правового феномена та намаганням по-новому поглянути на його значимість для людини. Як слушно вказує 3 цього приводу Ю.В. Барзілова, на початку розвитку людської цивілізації поняття «право», «обов'язок», «відповідальність» не розрізнялись, а були злиті воєдино. Згодом останні почали диференціюватись, проте все ж розвивались паралельно, тісно взаємодіючи між собою. Дослідниця також зауважує, що сфера обов'язків у контексті історичного розвитку переважно перебувала в «тіні» прав, тобто сприймалась як «другорядна». При цьому розуміння єдності прав та обов'язків залишалось ${ }^{1}$. Подібну позицію підтверджує Р.Р. Карімова, зазначаючи, що сучасне правове існування обов'язків здійснило відрив від їх внутрішнього ціннісного субстрату, залишивши лише зовнішню оболонку повинності. Право лише легітимує внутрішні обов'язки людини, «відриває» їх від іiї внутрішнього статусу, огортає в форму імперативності і повертає людині, позбавляючи її еквівалентної взаємодії з державою, перетворюючи людину із суб'єкта права на його об'єкт. Так руйнується внутрішній, вольовий характер самозобов'язування та виникає протидія юридичним обов'язкам². Сучасна людина західної цивілізації надає значну увагу своїм правам та свободам, завдяки чому останні сприймаються в якості цінності, натомість значимість обов'язків практично нівелюється. Науковці ж цілком виправдано наголошують на тому, що права не можуть ефективно реалізовуватися без обов'язків. Лише в гармонійному поєднанні обох явищ можливий прогресивний розвиток суспільства та держави.

Стан наукового дослідження. Категорія обов'язку як філософське поняття отримує своє підгрунтя у працях таких мислителів, як: Цицерон, Г. Гроцій, Б. Спіноза, С. Пуфендорф, І. Кант, Ж-.Ж. Руссо, Ш.-Л. Монтеск'є тощо. Юридичний обов'язок на теоретико-правовому рівні досліджувався Ю.В. Барзіловою, Н. Герваген, Т.С. Грачовим, Б.С. Ебзеєвим, Р.Р. Карімовою, О.П. Карманюком, І.В. Коршуновою, О.О. Рудаковим, Ю.Г. Ткаченком, О.М. Хохловою, О.П. Черновол, Е.А. Юнусовим, І.Р. Юрчак та іншими вчениминауковцями.

Що ж до категорії правова цінність, то вона також, як і обов’язок, має свої філософські підстави обгрунтування й розуміння. Так, перші грунтовні розробки цінностей можемо спостерігати у спадщині представників неокантіанської філософської школи (Г. Ріккерт, В. Віндельбанд, Г. Радбрух та інші), а в подальшому Р.Г. Апресяна, Н. Гартмана, А.А. Гусейнова, М. Лосського, В. Малахова, Т. Парсонса, М. Шелера та інших. Поряд із тим у юридичному сенсі категорію правових цінностей у різних контекстах досліджували О.М. Бабенко, М.С. Балаянц, К.В. Горобець, О.Г. Данильян, О.П. Дзьобань, К.А. Жебровська, А.О. Маргушина, С.В. Михайлов, Н. Неновскі та інші. Попри вищезазначене, аналіз стану наукових розвідок щодо окресленої проблематики свідчить про те, що вчені лише опосередковано зачіпали подібну сутнісну характеристику феномена юридичного обов'язку.

Формулювання мети статті. Мета нашого дослідження полягає у спробі обгрунтувати особливості юридичного обов'язку як самостійної правової цінності. Досягнення даної мети передбачає розв'язання, принаймні, таких завдань, як: 1) з'ясування розуміння правових цінностей та юридичного обов'язку, які використовує правова наука; 2) доведення можливості визнання юридичного обов'язку в якості правової цінності; 3) формулювання поняття юридичного обов'язку як правової цінності.

Виклад основного матеріалу. В філософії права має місце окремий розділ - аксіологія права - предметом дослідження якого постають правові цінності. Як зазначає О.О. Бандура, аксіологія права займається вивченням ціннісного аспекту права, а також досліджує ціннісні аспекти юридичної науки та освіти․

У правовій науці розмежовуються поняття «правові цінності» та «цінності права». Таке розуміння відповідає підходу щодо виокремлення аксіологією права цінностей-цілей та цінностей-засобів. 3 точки зору

(C) Т.П. Попович, 2020

* Tereziia Popovych, Ph.D. in Law, Associate Professor, Associate Professor of Uzhhorod National University 
I. Вороніної, правові цінності є такі цінності, які розкривають власну значимість права (суб'єктивне право, юридичний обов'язок, законність, юридична відповідальність, правовий статус). У свою чергу, цінності права є різноманітні матеріальні та нематеріальні блага, які забезпечуються правом (життя, свобода, власність тощо $)^{4}$. Отже, серед правових цінностей дослідницею названо юридичний обов'язок, який, поряд 3 іншими, визначає значимість права як такого.

В основу ж обгрунтування права як цінності В. Рожковський ставить той фактор, чи сприяє право самореалізації людини, породжує нові можливості для розвитку людини та суспільства. Відтак, правові цінності призначені для створення, підтримки та зміцнення соціального порядку й дисципліни, нормального функціонування суспільства 5 . Юридичний обов'язок, варто зауважити, й постає одним із засобів забезпечення порядку й дисципліни в суспільстві.

На думку Х. Габаковської, право як ціннісне за своєю природою утворення являє собою певну систему «належного бути» як систему загальнообов'язкових, семантично орієнтованих ідеальних утворень - норм соціальності й комунікації людей. Дослідниця стверджує, що в основі розуміння сутності права лежить специфічна форма організації людиною свого буття як світу цінностей, джерела якого мають антропологічний характер і пов'язані з такими феноменами, як справедливість, обов'язок, відповідальність. Спочатку такий світ цінностей утілювався у системі звичаїв і моралі, тоді як з виникненням державності вказані норми набувають форми жорстко фіксованих («повинно бути так і не інакше») законів чи правових норм ${ }^{6}$. Виходячи 3 таких позицій, категорія юридичного обов'язку цілком логічно адаптовується під явище правових цінностей і стає одним із способів їх втілення.

На сьогодні мають місце різноманітні підходи до тлумачення сутності права: неонормативістська, комунікативна, лібертарна, антропологічна, ціннісно-нормативна. Відповідно до ціннісно-нормативного підходу, як зазначає К.В. Горобець, право являє собою таку систему, що історично склалась, морально обгрунтована й релігійно вивірена, легалізована та ціннісно-нормативна, яка розрахована на всезагальне визнання та відповідну поведінку людей, організацій, соціальних спільнот тощо. При цьому дослідник також додає, що, попри різні підходи до пояснення сутності права, визнання його ціннісних основ можна сприймати як універсальну ідею всіх існуючих концепцій праворозуміння, що дає змогу співіснувати їм усім у рамках єдиної парадигми, яку автор пропонує називати ціннісно-плюралістичною парадигмою юриспруденції․ У розрізі зазначеного вартою уваги є позиція К.А. Жебровської, яка в рамках дисертаційного дослідження аналізує два основні напрями пояснення змісту правових цінностей:

1) універсалізм; даний підхід грунтується на визнанні біологічного (а не культурного) фактору людини як такого, що визначає іï природу; завдяки цьому має місце переконання, що, оскільки природа людини не залежить від культурних факторів, то й правові цінності єдині для всіх, тобто мають універсальний характер; своє закріплення такий підхід отримав у фундаментальних міжнародних документах та регіональних стандартах з прав людини;

2) релятивізм; постає протилежною позицією до універсалізму й виходить 3 того, що природа людини визначається передусім культурними факторами, а тому залежить від суспільства, цивілізації тощо, які й формують світоглядні позиції людини; релятивна концепція стоїть на засадах культурного різноманіття й прагнення відстоювати свою ідентичність та унікальність 8 .

У разі сприйняття позиції К.А. Жебровської поняття юридичного обов'язку можна характеризувати водночас як з точки зору універсалізму, так і релятивізму. Так, якщо брати до уваги біологічну (природну) складову людини, то при обгрунтуванні обов'язку можна спиратися на природний моральний закон, що закладений у кожній людині як живій істоті. Даний закон апріорно передбачає виникнення в особи обов'язків щодо інших людей. Це дає нам підстави стверджувати про взаємозалежність прав і обов’язків як явищ, що мають природне походження. Тоді як, соціальність людини як живої істоти сприяє тому, що вона повинна наділятися певним спектром обов'язків з метою підтримання гармонійної взаємодії в суспільстві. Водночас «юридичний» як характеристика специфіки обов'язку вказує на феномен права, який так чи інакше пов'язаний $з$ державою як суспільним інститутом, а отже, є елементом культури (культурна форма співжиття людей у рамках певного суспільства).

У свою чергу, А.М. Бабенко пов'язує виникнення правових цінностей з народженням особи - носія індивідуальних форм свідомості та діяльності, що потребувало регулювання відносин між нею та державою9. Дослідник зазначає, що саме держава визначає ієрархію правових цінностей суспільства. Ефективно регулюючи суспільні відносини, ця система відповідає традиційним цінностям культури суспільства, інакше ж виникає руйнування старих та відторгнення нових цінностей, що призводить до ціннісної дезорієнтації громадян ${ }^{10}$. Серед іншого цінність права визначається такими його ознаками, як нормативність, загальнообов'язковий характер, забезпечення дотримання правових приписів з боку держави. Цінність права полягає також у тому, що воно забезпечує порядок та організованість в соціумі11. Таким чином, розуміння правових цінностей А.М. Бабенком є позитивістським за своїм характером. Виходячи з такого бачення, і категорія обов'язку виникає лише в результаті формування держави (природне походження обов'язку заперечується), покликання якої полягає у визначенні соціально допустимої поведінки для громадян, яка б забезпечувала цілісність та гармонійність розвитку суспільства.

Вчений-теоретик М.С. Балаянц у рамках дисертаційної роботи, присвяченої фундаментальним правовим цінностям сучасного суспільства, формулює правові цінності як такі, що переживаються людьми й визначаються культурою форми позитивного ставлення до правової системи суспільства, які обумовлюють вибір поведінки, відповідний цій системі, юридичну оцінку подій, та постають принципами регенерації правового життя. Правові цінності допомагають оцінювати оточуючий особу світ та події з правових позицій, а також обирати й формувати свою правову поведінку, завдяки чому органічно вплітаються в систему норма- 
тивного регулювання суспільства. В якості критерію установлення первинних загально значимих цінностей М.С. Балаянц пропонує визначити наступний принцип: «слід турбуватися про такі спільні цінності, здійснення яких необхідне для реальної можливості всіх суб'єктів жити відповідно до своїх орієнтирів»12. У цьому контексті доречно зазначити, що саме завдяки правовому втіленню обов'язків і можливе забезпечення у суспільстві інтересів усіх його членів, оскільки обов'язок звертає увагу особи на ту поведінку, яка була б корисною для всіх його членів. Таким чином, внаслідок свого нормативного закріплення обов'язок отримує загальну значимість.

Якщо опиратись на положення дисертаційного дослідження С.В. Михайлова, то відповідно до їх змісту правові цінності являють собою, з одного боку, необхідний для досягнення ідеал, який пронизує всі рівні та сфери правових зв'язків і правовідносин, а з іншого - найважливіші та глибинні принципи, які визначають ставлення особи та суспільства до права 13 .

Водночас А.О. Маргушина виходить з позиції поєднуваності й невід’єднуваності правового порядку та правових цінностей. Правові цінності без правового порядку, доходить висновку дослідниця, безцільні, а правовий порядок без правових цінностей - недієвий. Це пов'язано з тим, що правова цінність не може вважатися такою формою поведінки, яка не забезпечена можливістю державного примусу14. Додамо до цього, що кожен юридичний обов'язок забезпечується силою державного примусу за його порушення, в результаті чого настають заходи юридичної відповідальності.

Отже, виходячи з окреслених підходів до розуміння правових цінностей, останні (з метою подальшого обгрунтування юридичного обов'язку як правової цінності) визначимо як ідеальні правові утворення та принципи, що визначають уявлення про значимість права, здійснюють за допомогою права оцінку явищ, які відбуваються у соціумі, формують певну модель правової поведінки особи та які призначені для забезпечення правового порядку в суспільстві. Вони також втілюють сформовані орієнтири й пріоритети та $є$ засобами для досягнення правом своєї мети та поставлених цілей.

Окрім того, правові цінності отримують своє відображення й фіксацію в правосвідомості та правовій культурі суспільства й окремого індивіда, в кінцевому результаті втілюючись в практичній активності членів суспільства 15 . Юридичні ж обов'язки, як наголошує Ю.В. Барзілова, це невід'ємний елемент правосвідомості та правової культури суспільства. При цьому залежність юридичних обов'язків і правосвідомості та правової культури прямо пропорційна: чим нижчим є рівень правової свідомості та правової культури суспільства, тим гірше виконуються обов'язки, а отже, порушуються права та інтереси, поширюється правовий нігілізм, послаблюються порядок і дисципліна в державі ${ }^{16}$. Таким чином, вважаємо, що дотичність правових цінностей та юридичного обов'язку до правосвідомості та правової культури ще більше пов'язує та поєднує дані категорії (цінностей та обов'язку).

Звертаючись до аналізу окремих позицій вчених, безпосередньо пов'язаних із розкриттям природи юридичного обов'язку, зазначимо, що Є.І. Джумурат його специфікою визначає те, що він постає засобом реалізації інтересів як зобов'язаного, так і правомочного суб'єкта. Обов'язок підлягає виконанню незалежно від усвідомлення та волевиявлення суб' єкта ${ }^{17}$. Тут варто зробити одне застереження щодо виконання юридичного обов'язку незалежно від усвідомлення та волевиявлення особи. Цей аспект може мати дві складові. 3 одного боку, закріплення юридичних обов'язків на нормативному рівні державою де-юре передбачає їх виконання незалежно від того, наскільки особа усвідомлює їх сутність та значення. Проте, з іншого боку, де-факто виконання нормативно визначених державою юридичних обов'язків необхідним чином потребує волевиявлення особи. Іншими словами, те, якою мірою особа виконує покладені на неї державою обов'язки, залежить насамперед від того, чи сприймає вона відповідний обов'язок як певний орієнтир, пріоритет, цінність. Завдяки цьому відкривається прямий шлях до обгрунтування юридичного обов'язку як окремої правової цінності.

На думку ж А.П. Панова, юридичний обов'язок $є$ продиктована реаліями суспільного розвитку державно-доцільна необхідність належної поведінки особи, що закріплена на законодавчому рівні18. У правовому приписі, зазначає В. См, держава в формі повинності виражає соціально обумовлену необхідність певної поведінки суб'єктів ${ }^{19}$. При цьому зауважимо, що правові цінності також обумовлюють певну модель поведінки особи в суспільстві через надання їй правової оцінки.

Згідно з позицією Ю.В. Барзілової, юридичний обов'язок є вид і міра державно доцільної, розумної, корисної, об'єктивно обумовленої поведінки. В її основі лежить необхідність певної поведінки, що обумовлена правовими нормами, а сутність юридичного обов'язку полягає в його державно-правовій необхідності ${ }^{20}$. Варто погодитись із Ю.В. Барзіловою у тому, що без обов'язків правовий статус особи був би хитким і нестійким, який би не відображав необхідної збалансованості інтересів особи, суспільства та держави. Принцип єдності прав та обов'язків зміцнює правове становище особи. Важливо при цьому, щоб виконання обов'язків у суспільстві базувалось не на страху можливого примусу через їх невиконання, а на силі переконаності в справедливості та соціальній доцільності обов'язків, усвідомлення їх об'єктивної необхідності 21. Із врахуванням того факту, що виконання юридичного обов'язку повинне грунтуватися на переконаності особи в його справедливості та соціальній доцільності, також логічним є зв'язок правових цінностей 3 юридичним обов'язком, виходячи з розуміння правових цінностей як відповідних ідеальних правових утворень та принципів, що слугують формуванню в особи певної моделі правової поведінки.

Сучасна правова наука виходить 3 постулату про невіддільність та взаємозалежність прав та обов'язків людини та громадянина. Проте все ж варто розуміти їх принципові відмінності. Так, А.С. Шабуров зазначає, що право виникає в умовах відособлення окремого індивіда від общини, роду, становлення його як самостійного та автономного. У свою чергу, обов'язок визначається не характером окремої особи, але соціального цілого, як засіб його збереження та розвитку22. Отже, якщо брати до уваги ті аспекти природи обов'язку, метою яких є підтримання належного рівня розвитку та ефективного функціонування соціуму, то він постає 
однією з фундаментальних правових цінностей, адже показує значимість ролі індивіда в суспільстві, соціальну природу людини.

Відповідно до класичної концепції природного права, обгрунтованої мислителями Нового часу, єдиною підставою виникнення природних прав людини є факт існування самої людини, у той же час як 3 обов’язком ситуація складніша. Тут умовою буття обов'язку виступають усвідомлена воля та інтереси колективного цілого, соціуму, які відповідний обов'язок і буде виражати, а також механізм примусу, який би забезпечував виконання такого обов'язку. Тому функціонування природних прав людини, на думку А.П. Панова, має об'єктивні підстави, тоді як функціонування «природних» обов'язків неможливе. Характер останніх завжди обумовлений інтересами й установками колективу чи суспільства, частиною якого є індивід 23 .

Водночас Т.А. Француз-Яковець акцентує увагу на тому, що зв’язок між правами і свободами, з одного боку, та обов'язками, з іншого - зумовлюється тим, що будь-які правовідносини, які виникають між окремими особами як членами суспільства, а також між особою і державою, завжди мають двосторонній характер. Тому, якщо один із суб'єктів зазначених правовідносин отримує певне право щодо іншого, то й інший суб'єкт разом з обов' язком, що кореспондує цьому праву, отримує відповідне право 24 . На підставі такого підходу напрошується висновок, згідно з яким якщо право (в його природному сенсі) виражає біологічну природу людини, то обов'язок - соціальну природу. Завдяки цьому й можливо говорити про необхідність гармонійного поєднання біологічного та соціального чинника в людині, а з точки зору права, - іï прав та обов'язків у суспільстві.

Разом $з$ тим у правовій літературі (Р.Р. Карімова, Е.А. Юнусов) має місце позиція, що природна сутність обов'язку випливає зі справедливості як його фундаменту. Більше того, природні обов'язки в кожному конкретному суспільстві такі, якими є критерії справедливості, що визначають їх зміст ${ }^{25} .3$ точки зору Р.Р. Карімової, справедливість у цьому сенсі постає внутрішньо усвідомлюваним стимулом до самозобов'язування 26. Цікаво, що окрім засади справедливості, з якої випливає усвідомлення юридичного обов'язку в його природно-правовому розумінні, дослідниця також інтерпретує обов'язок як необхідний елемент свободи людини, що виконує функції узгодження, збереження, спрямування індивідуальної свободи. В обов'язку одночасно сконцентровані цінності, інтереси та свободи суб'єкта соціуму27.

У цілому ж слід зазначити, що питання стосовно природного чи соціального трактування походження обов’язку залишається дискусійним у науковій літературі. Відповідь на нього, безсумнівно, потребує окремого більш грунтовного аналізу, який буде здійснено нами в подальших дослідженнях, адже вона, окрім іншого, безпосередньо впливає й на формування позиції щодо особливостей природи юридичного обов’язку як самостійної правової цінності.

Висновки. Отже, в ході проведеного дослідження ми сформулювали поняття правових цінностей як ідеальних правових утворень та принципів, що визначають уявлення особи про значимість права, оцінку явищ, які відбуваються в суспільстві, з допомогою права, формують певну модель поведінки особи, та які призначені для забезпечення правового порядку й дисципліни в суспільстві. Враховуючи вказане розуміння правових цінностей, а також позиції сучасної правової науки щодо сутності юридичного обов'язку, визначимо поняття юридичного обов'язку як правової цінності: це правовий припис, що формулюється державою як необхідна для забезпечення правопорядку модель поведінки особи, встановлюється з метою підтримання належного функціонування суспільства як колективного цілого й забезпечення інтересів усіх його членів $\mathrm{i}$ виконується на основі сприйняття відповідної поведінки як справедливої та соціально доцільної. Обгрунтування юридичного обов'язку як правової цінності можливе завдяки: 1) сприйняттю особою відповідної поведінки як необхідної, справедливої, соціально допустимої, що виражає суспільно значимий орієнтир; 2) формулюванню державою за допомогою правової норми суспільно значимої поведінки; 3) реалізації завдяки такій поведінці соціальної природи людини як частини колективного цілого; 4) утіленню принципу взаємозалежності та взаємодоповнюваності прав і обов'язків особи.

\footnotetext{
1 Барзилова Ю.В. К вопросу об истории развития института юридических обязанностей. Известия Саратовского ун-та. Экономика, управление, право. 2007. Вып. 2. С. 58.

2 Каримова Р.Р. Юридические обязанности: сущность и проблемы реализации: автореф. дис. ... канд. юрид. наук: 12.00.01. Екатеринбург, 2008. С. 6-7.

3 Бандура О.О. Аксіологія права як складова філософії права. Філософські та методологічні проблеми права. 2015. № 1-2. C. 46 .

4 Вороніна І. Правові цінності в системі соціально-політичного управління суспільством. Национальный юридический журнал: теория и практика. 2016. № 2. С. 6.

5 Рожковский В. Право как ценность и правовые ценности. Thesaurus. 2017. Вып. 4. С. 238-239.

${ }^{6}$ Габаковська Х. Аксіологічна природа права: теоретико-пізнавальний підхід. Вісник Національного університету «Львівська політехніка». Юридичні науки. 2017. № 865. С. 69-70.

7 Горобец К.В. Универсализм правовых ценностей. Актуальні проблеми держави і права. 2011. Вып. 61. С. 325-326.

8 Жебровська К.А. Правові цінності у взаємодії правових систем: автореф. дис. ... канд. юрид. наук:12.00.01. Одеса, 2017. C. $8-9$.

9 Бабенко А.Н. Правовые ценности и освоение их личности: автореф. дис. ... канд. юрид. наук: 12.00.01. Москва, 2002. С. 3.

10 Там само. С. 14.

11 Там само. С. 21

12 Балаянц М.С. Фундаментальные правовые ценности современного общества: автореф. дис. ... канд. юрид. наук: 12.00.01. Москва, 2007. С. 15-16.
}

13 Михайлов С.В. Правовые ценности: теоретико-правовой аспект: автореф. дис. ... канд. юрид. наук: 12.00.01. Волгоград, 2011. С. 15-16. 
14 Маргушина А.А. Правовой порядок и правовые ценности: институционально-правовой анализ: автореф. дис. ... канд. юрид. наук: 12.00.01. Краснодар, 2013. С. 18.

15 Там само. С. 21.

16 Барзилова Ю.В. Юридические обязанности как элемент правового статуса личности: автореф. дис. ... канд. юрид. наук: 12.00.01. Саратов, 2006. С. 22.

17 Джумурат Є.І. Забезпечення виконання конституційних обов'язків людини і громадянина у сфері місцевого самоврядування в Україні: автореф. дис. ... канд. юрид. наук: 12.00.02. Київ, 2011. С. 17.

18 Панов А.П. Система конституционных обязанностей граждан Российской Федерации: автореф. дис. .... канд. юрид. наук: 12.00.02. Саратов, 2008. С. 10.

19 Ем В. Категории обязанности в советском гражданском праве: вопросы теории: автореф. дис. ... канд. юрид. наук: 12.00.03. Москва, 1981. С. 9-10.

20 Барзилова Ю.В. Вказана праця. С. 18-19.

21 Там само. С. $15-16$.

22 Шабуров А.С. Обязанности человека в рамках концепции прав человека. Вестник Тюменского гос. ун-та. Право. 2012. № 3. C. 199.

23 Панов А.П. Естественные обязанности человека: миф или реальность? Известия Саратовского ун-та. Экономика, управление, право. 2012. Вып. 1. С. 122.

24 Француз-Яковець Т.А. Забезпечення конституційно-правового статусу людини і громадянина в Україні: автореф. дис. .... канд. юрид. наук: 12.00.02. Одеса, 2007. С. 12.

25 Юнусов Э.А. Правовые обязанности человека и гражданина (вопросы теории): автореф. дис. ... канд. юрид. наук.: 12.00.01. Москва, 2008. С. 17-18.

26 Каримова Р.Р. Юридические обязанности: сущность и проблемы реализации: автореф. дис. ... канд. юрид. наук: 12.00.01. Екатеринбург, 2008. С. 8.

27 Там само.

\section{Резюме}

Попович Т.П. Юридичний обов'язок як правова цінність.

У статті розкриваються окремі аспекти розуміння правових цінностей та юридичних обов'язків у сучасній правовій науці. Автор доводить можливість визнання юридичного обов'язку в якості правової цінності й формулює відповідне поняття. Пропонується авторський підхід до обгрунтування юридичного обов'язку як правової цінності завдяки наступним факторам: сприйняттю особою відповідної поведінки як необхідної, справедливої, соціально допустимої, що виражає суспільно значимий орієнтир; формулюванню державою за допомогою правової норми суспільно значимої поведінки; реалізації внаслідок такої поведінки соціальної природи людини як частини колективного цілого; утіленню принципу взаємозалежності та взаємодоповнюваності прав і обов'язків особи.

Ключові слова: обов'язок, юридичний обов'язок, правова цінність, цінності права, права людини, правовий порядок.

\section{Резюме}

\section{Попович Т.П. Юридическая обязанность как правовая ценность.}

В статье раскрываются отдельные аспекты понимания правовых ценностей и юридических обязанностей в современной правовой науке. Автор доказывает возможность восприятия юридической обязанности в качестве правовой ценности и формулирует соответствующее понятие. Предлагается авторский подход к обоснованию юридической обязанности как правовой ценности благодаря следующим факторам: восприятию лицом соответствующего поведения как необходимого, справедливого, социально допустимого, такого, что выражает общественно значимый ориентир; формулировке государством с помощью правовой нормы общественно значимого поведения; реализации в результате такого поведения социальной природы человека, как части коллективного целого; воплощению принципа взаимозависимости и взаимодополняемости прав и обязанностей человека.

Ключевые слова: обязанность, юридическая обязанность, правовая ценность, ценности права, права человека, правовой порядок.

\section{Summary}

\section{Tereziia Popovych. Legal obligation as the legal value.}

The article describes some aspects of understanding legal values and legal obligations in modern legal science.

To achieve the goal of the study, the author envisaged the performing such tasks as: clarifying the understanding of legal values and legal obligations used by legal science; proving the possibility of recognizing a legal obligation as a legal value; formulation of the concept of legal obligation as a legal value.

The author traces the interrelation between legal values and the legal order, emphasizing that without legal values, the rule of law is ineffective, in turn, - legal values outside the legal order have no practical content.

Based on this, the author proposes his own definition of the concept of legal values as ideal legal entities and principles that determine a person's perception of the importance of law, assessment of phenomena occurring in society through law, form a certain model of legal person's behavior and are designed to ensure legal order and discipline in society.

Given this understanding of legal values, as well as the position of modern legal science on the essence of legal obligation, the author defines the concept of legal obligation as a legal value: this is a legal prescription which is formulated by the state as necessary to ensure law and order model of individual behavior, established in order to maintain the proper functioning of society as a collective whole and to ensure the interests of all its members, and fulfilled on the basis of the perception of certain behavior as fair and socially appropriate. The author's approach to the justification of a legal obligation as a legal value is proposed due to the following factors: the person's perception of the relevant behavior as necessary, fair, socially acceptable, which expresses a socially significant benchmark; the formulation by the state through the legal norm the socially significant behavior; realization through such behavior the human social nature as a part of the collective whole; the implementation of the principle of interdependence and complementarity of the rights and obligations of the individual.

Key words: obligation, legal obligation, legal value, values of law, human rights, legal order 